\title{
E-government: What Is It, and Will It Transform Government?
}

\author{
Robin Gauld
}

\begin{abstract}
E-Government uses improved Internet-based technology to make it easy for citizens and businesses to interact with the government, save taxpayer dollars, and streamline citizen-togovernment communications.
\end{abstract}

Bush (2002)

We see e-government enabling a transformation in the way government operates and delivers results for New Zealanders.

Mallard (2003)

Like many trends that influence public policy and administration, 'e-government' is a multifaceted and nebulous idea, easily applied to a range of different situations, across the entire gamut of government and society, and with differing intentions. There are wideranging claims made for e-government, considerable hopes pinned on it, and substantial commitments financial and otherwise - made to it. The concept has been embraced by political leaders; it is being used to drive changes to the public sector, and to legitimise investment of public money in information and communications technology (ICT). An important question, however, is what 'e-government' is, and what shape an 'e' government might have. This article overviews the concept, the developmental phases of e-government and some international and local policy developments, and speculates on the impact of ICT on the future shape of government.

\section{What is e-government?}

E-government might be defined as: (1) ICT, and, specifically, internet and web-enabled public service activity; and (2) the explicit coordination and oversight by central government of this, and of public sector ICT strategy and policy development.

\section{Expectations of e-government}

There are varying e-government expectations, both practical and theoretical.

\section{Managerial}

Through a managerial lens, ICT is viewed as a tool of efficient administration, responsive to the needs of the 'new [knowledge] economy'. Information flows are twoway, between government and consumers, and servicecentred, although the primary focus is on improving intra-government information exchange and capacity to deliver on government objectives. The logic of the system is 'service delivery', and policy and information presentation. A primary expectation is that ICT will integrate information from disparate sources, and reduce public service staff as website information replaces the need for them. A related expectation is that availability of government information and services will increase.

\section{Government coordination and transformation}

A second set of expectations revolves around the notion of government coordination and transformation - that ICT will reverse government 'fragmentation' while centralising control of information and policy activity. The hope is that ICT will break down walls between the many agencies often involved in delivering services as they become interconnected. For the public, confusion over which agency to approach will be reduced. In keeping with this, the relevance of individual government departments will come under scrutiny, particularly where websites become the focus of, and point of interaction for, users of specific services. For example, in any developed country, children, the elderly and welfare recipients will each obtain services from a range of agencies, such as education, welfare, employment, social work and health. Web 'portals' that integrate information about and provide links to services 
for specific groups provided by disparate agencies promise to provide 'one stop' service and a focus for government agencies.

A further expectation is that public administration and policy making will undergo a fundamental transformation to the 'e-government paradigm' (Ho, 2002). In the e-government paradigm, work is routinely conducted beyond the physical boundaries of individual agencies. Networks of policy makers from across and beyond government with relevant expertise around policy issues are assembled and function in cyberspace. The result, in theory, is increased collaboration, improved policy capacity and a heightened customer service focus, as well as reductions in the 'gap' between high-level central government policy makers and those implementing policy at the frontline of service delivery. With the focus away from individual departments, governments need to examine how their agencies and policy work should be structured, funded and monitored (Fountain, 2001). For instance, should agencies remain independent administrative units, or should mergers and downsizings that align with web-based and electronic service delivery be pursued?

\section{Participation}

The idea of participation frames a third set of egovernment expectations. There are two variations on this theme. The first is consultation, in which ICT is viewed as a tool for developing better policy responses to electronically-articulated public needs. A core aim is to boost public education and involvement in policy and public service design. Following this, interest groups, agencies, associations and individuals may all interact and develop advocacy coalitions within cyberspace and use information in the quest to influence government. E-government may also extend to the development of electronic democratic arrangements such as voting and referenda systems, opinion polling, advisory groups, electronic public meetings and other feedback mechanisms.

The second variant stems from theories of 'deliberative' or 'direct' democracy. From this perspective, an egovernment aim is enhanced deliberation, participation and, ultimately, democracy. Unlike the consultative (and managerial) model, where the state maintains a position of control, in the deliberative model the government's role is minimised to that of regulating infrastructure and mediating public exchange. Deliberation, in its purest form, conceives of political processes as governed by a shared aim of achieving consensus, with no one interest or player exerting undue pressure or influence on proceedings. Information flows are complex and operate across an array of forums, including discussion groups, email list servers, interactive websites, mobile devices and so on. Researchers have found that the existence of the 'digital divide', between those who do and those who do not have ICT access, undermines the potential for deliberative democracy (Thomas and Streib, 2005; Wicklund, 2005). Universal computer access and capacity to contribute are, therefore, crucial.

\section{Fulfilling the expectations}

E-government clearly has elements relevant to both internal (within and across government and its agencies) and external (interactions between government and society) functions, with widespread implications for the structure of the state. Of course, the expectations outlined above are simply that, and no country in the world is presently anywhere near fulfilling them. Furthermore, meeting these expectations hinges on the preferences and priorities of politicians and the public, as well as a variety of other factors, the evidence for which is mixed. These include:

- that ICTs and the information made available via them are user-friendly;

- that the information that agencies might encounter in their data gathering is readily accessible and digestible; and

- that the public and businesses have access to computers and prefer to interact with government services in this way.

Research shows that United States citizens actively use email and the internet for 'informational' services such as recreation and tourism. However, 'transactional' egovernment services are much less used, with, for example, only $15 \%$ of tax forms submitted online (Reddick, 2005). In addition, those who visit government websites are more likely to be universityeducated and well off than those who do not, confirming a digital divide (Thomas and Streib, 2005).

Goals such as reducing fragmentation rely not only on robust ICT development and the availability of technologies that assist inter-agency collaboration. Also 
required is the building of good working relationships between groups and agencies involved in service delivery, as well as the identification of issues and services conducive to inter-agency delivery. Without tight inter-agency coordination, service users may be led to believe they are being provided with a seamless service, only to find that, if difficulties arise, they still have to deal with individual agencies. Similarly, there is no example yet in the world of ICT driving a genuinely integrated government whose separate agencies are not identifiable. Whether transparency will increase is also questionable: it may be that only information deemed relevant or tailored for public consumption will be placed on websites; that much of the internal email communication and work that feeds into policy will not be placed in agency archives; and that the increased volume of available information will serve to confuse the public.

Naturally, in keeping with ICT advances, procurement and application, and the development of public policy, e-government is an evolutionary process. Some parts of government will be more digitised than others, and some expectations will be easier to achieve. The factors affecting this include strategic commitment to ICT procurement strategies and website development, financial and human resources, and, of course, the nature of activity (some departments, such as those responsible for immigration and tax collection, will have more public interaction than others, such as finance). Egovernment development also relies on the commitment of government and its agencies - the extent to which the 'e' means simply computerising of existing government functions rather than transforming organisations - as well as public trust and satisfaction with electronic systems. Finally, political leaders may promote some dimensions of e-government more than others. Researchers in Austria found that politicians there readily promoted 'e-government' for improving administration, but showed minimal interest in developing 'e-democracy', as this would reduce their power and control (Mahrer and Krimmer, 2005).

\section{E-government developmental phases}

Various writers (e.g. Layne and Lee, 2001) have discussed the 'phases' of e-government development. In the first phase, attention is on electronic cataloguing of information. This phase involves government departments creating websites providing information about services, downloadable forms and documents, and contact details.

The second phase, moving towards 'two-way' communication, involves development of more sophisticated websites that link internal systems with online presence, allowing citizens to interact with government. For example, many transactions, such as paying of fines, registering for services and completing tax returns, will be conducted electronically. Here, close attention must be paid to security issues and technical detail. Systems for online transactions, for instance, need to be designed to ensure public confidence. Furthermore, data must be automatically transferred to the correct internal systems.

In the third phase, often termed 'vertical integration', local agencies and their services become connected with central systems so that any interaction with a local service is automatically relayed to relevant central agencies. This phase sees the development of 'portal' websites that feature related services from a range of central and local agencies. Examples include financial and business services (featuring both government and the private sector), welfare and health, and customs and immigration.

The fourth phase sees genuine 'horizontal integration' of government services. To clients, any walls between services and agencies will not be apparent, as systems have become fully integrated and interactive. Instead of the public having to navigate agencies (or portals) to obtain or transact with various services, these take on a seamless quality, with people having 'one stop' access to services. This, of course, may have implications for the structure of government, as Silcock (2001, p.90) suggests: 'in some cases, new departments will have formed from the remains of predecessors. Others will have the same names, but their interiors will look nothing like they did before e-Government.'

Most of the world's governments have reached at least the first phase. Many have moved into the second. The first two phases can be seen as 'add-ons' to existing public sector structures and work. The third and fourth phases require more sophisticated ICT, while the fourth also necessitates substantial public sector work redesign. The hurdles to achievement of vertical and horizontal integration are, therefore, much greater than the simple 
email and web presence required for the first two phases. Implicit in phases three and four is also an assumption that the technology and the technical personnel implementing them are available, capable and reliable, and able to fulfil promises.

\section{A brief review of international e-government developments}

Many governments have launched wide-ranging and ambitious e-government programmes. This section outlines developments in Australia, Britain, the United States and New Zealand. Each country shares a comparable history of embracing ICT, considering it to drive prosperity, improve efficiency and create seamless citizen-focused services. Each has issued successive e-government strategies and established a coordinating office. Each faces several challenges.

\section{Australia}

Australia was early and swift in embracing the egovernment concept. In 1997 the government announced that all Commonwealth agencies should aim to have appropriate services available online by December 2001; that electronic payments would become the normal means for the Commonwealth government by 2000; and that a government-wide intranet would be created.

In 2000 the Commonwealth government unveiled its Government Online strategy. This outlined eight 'strategic priorities', such as taking 'full advantage of opportunities provided by the internet'. Government Online also provided information on data standards and information exchange protocols with which agencies were expected to comply.

An updated strategy was issued in 2002, reinforcing the desire for secure and trustworthy crossgovernment service integration. Notably, each Australian state government has its own e-government office, leading to several state differences and militating against interoperability. Moreover, a recent Audit Office report noted that key agencies were failing to measure the effectiveness of their ICT advancements, and were thus unable to determine whether services had improved or whether the government was getting good value for money (Australian National Audit Office, 2005).
International studies have ranked Australia a world leader in e-government, though Australian developments are still in their infancy. While most Commonwealth and state government departments have achieved the first two developmental phases outlined above, movement into the next two stages vertical and horizontal integration - remains largely in the planning and piloting phases.

\section{Britain}

In Britain, 'e-government' was first highlighted in 1996 with the release by the Conservative administration of Government.Direct. Since then, e-government has been central to New Labour's 'modernisation' programme, which aims to centralise and coordinate policy making, build more responsive and collaborative government and engage with the public. In 2000 the government announced that all appropriate services should be electronically available by 2005, a target largely achieved. A succession of new institutional arrangements have been introduced, including the creation of an e-minister, an Office of the e-Envoy (replaced in 2004 by the Office of E-Government) and individual departmental 'information age government champions'.

Future British priorities include ensuring that online services are accessible and universally used (2004 data showed that three-quarters of UK citizens had never visited a government website), and that web-enabled services change how people interact with government.

There is much hinging on future British e-government developments, as e-government was, in 2004, directly linked to an estimated loss by 2008 of over 84,000 civil service positions. This is predicted to result from reducing administrative costs and 'back office' functions (Brown, 2004).

In tandem with e-government, the New Labour government has also put considerable effort into developing 'joined-up government' (JUG), another strand of the modernisation programme. JUG corresponds with and is in part driven by e-government developments. JUG essentially refers to the achievement of horizontally- and vertically-integrated public sector activity.

\section{The United States}

In 1993 the US National Performance Review (NPR) viewed ICT as an essential factor in the 'reinvention' of 
government. By 1998, ICT application was claimed to have reduced the federal workforce by 351,000 people and saved \$US137 billion (Fountain 2001, p.21).

From 1998 e-government work became more serviceoriented and focused on developing 'virtual agencies' that bring together disparate services, and inter-agency e-government initiatives. By 2000 a wide range of virtual agencies (with services ranging from those relevant to the elderly and children to those for business, state services and education) had established a web presence via the federal FirstGov portal.

Developments have intensified since the passage of President George W. Bush's E-Government Act 2002. This outlined aims of ICT as a driver of inter-agency collaboration and 'results-oriented' citizen engagement, as well as various standards and initiatives, such as allowing private ICT companies to take a share in savings achieved through services provided to government.

A 2005 progress report deemed only nine out of 26 executive agencies successful in e-government implementation (see http://www.whitehouse.gov/ results/agenda/scorecard.html). Despite this, the United States was ranked number one in the 2004 United Nations e-government readiness index. Of course, each of the individual North American states also has e-government offices and strategies, further complicating consistent country-wide development.

\section{New Zealand}

Since 2000 there has been strong political commitment to e-government in New Zealand, underpinned by a desire for cross-governmental coordination.

New Zealand's first e-government strategy was released in April 2001. A year earlier the government announced its e-government 'vision': that 'New Zealanders will be able to gain access to government information and services and participate in democracy using the internet and ICTs as they emerge'. Although there appears to have been genuine interest in engaging the public, this has extended to no more than the provision of interactive e-services. Since 2005 something of a policy shift has been evident, with more explicit recognition of the capacity for ICT to build communities and public interaction, although commitment has so far been largely rhetorical.
The April 2001 strategy outlined a variety of aims, among them that New Zealand would an international e-government leader and that, by 2004, the internet would be the dominant means by which the public (and government itself) accesses government services and information. In terms of public sector structure, the strategy envisaged both 'seamless' service access and a 'seamless back office' (or in other words, reduced fragmentation among government departments).

The 2001 strategy listed a series of policy development and infrastructure milestones for completion by June 2002. These involved establishing a Secure Electronic Environment (SEE) to enable safe information exchange; a 'metadata' framework to ensure standard information cataloguing, to make public access straightforward; a web portal strategy and standards; a framework (later called 'e-GIF' - e-government interoperability framework) for common data policies and standards to ensure that government services can be connected; and a National Information Infrastructure Protection Strategy (NIIPS) to protect against hacking.

In December 2001 the strategy was updated, with issues needing attention, such as governance, funding and measuring e-government effectiveness, earmarked. A 2003 update (Mallard, 2003) confirmed previous policy directions and timetabled two important milestones, that:

- by 2007 , ICT will be integral to delivery of government services; and

- by 2010 the operation of government will have been transformed by the internet.

Achievements listed in the 2003 update included development of basic standards for e-government, and, at a practical level, an increasing range of online services accessible via the government portal (www.govt.nz). Again, security and, by implication, trust in egovernment, governance, funding and data quality standards and management topped the 'growing' list of 'challenges ahead' (Mallard, 2003, p.23). Governance (the management and guiding of ICT and e-government developments) poses particular challenges as agencies become interconnected. The strategy noted three facets of this: governance of shared inputs (joint use of information and technology), of outputs (integrated service delivery) and between levels of government (central and local). 
A 2004 progress report noted that the internet had become a dominant means of accessing government services particularly for those working in government, but that only around $28 \%$ of the general public regularly used the internet for engaging with government. In terms of fragmentation, the report found that most online services remained rooted in individual agencies, requiring users to contact several agencies in order to complete government transactions. Finally, while there appeared to be public demand for e-government, there was a lack of public knowledge about the information and services that government agencies supply online (State Services Commission, 2004).

In 2005 the government launched its Digital Strategy, with an agenda to use ICT to bring together government, business and communities 'to the benefit of all New Zealanders'. Outlined in the strategy are a range of initiatives, from increasing broadband uptake (New Zealand has high internet use but is at the bottom of OECD countries in terms of broadband penetration) to improving business and government productivity. Also in mid-2005, the 2007 and 2010 goals listed above were made one of the six new state sector development goals - namely, to 'use technology to transform the provision of services for New Zealanders'.

Of course, e-government aligns with various other state sector developments, particularly initiatives stemming from the State Services Commission's 2002 Review of the Centre report. This noted that ICT was relevant to its recommendations, including that the uncoordinated nature of public services and policy advice promoted by the managerialism of the 1990s be reversed, and the suggestion of the possibility of consolidating core government agencies into '7-10 super networks'. ICT also has relevance to the 'Managing for Outcomes' initiative aimed at coordinating agency goals and work.

\section{Conclusion}

'E-government' promises radical shifts in the way the public sector is organised and conducts its work, and in how the public navigates and accesses services. E-government is presently in an embryonic state, both internationally and in New Zealand. Numerous expectations and strategies are espoused by political and technology leaders, multiple initiatives are in progress, and considerable gains are anticipated. Furthermore, it is clear that there is an element of sloganeering attached to 'e-government' as a useful rhetorical device meaning all things to all people. It can be a managerial tool for creating efficiencies and cost cutting; a lever for better coordination of policy, administration and the organisation of government; and a vessel for enhanced participation, deliberation and democracy.

There are numerous unknowns, however, about the practice of e-government. It remains unclear, for instance, whether the promises of e-government will be realised or, as noted above, ICT will simply be an 'addon' to existing institutional arrangements, with additional costs. The issues surrounding implementation of e-government strategies and projects are complex and depend on many underlying and interconnected factors: resources, expectations, and social, organisational, legal and, of course, technical considerations. Moreover, e-government is a mammoth project in its own right for the simple reason that it applies to the entire public sector. When considered against the fact that the great majority of public sector ICT projects fail in one way or another, there may be cause for pessimism about whether the much broader e-government project can be achieved or, if it is, whether its shape, functioning and costs will match with predictions.

A key question for New Zealanders, of course, is: if the operation of government is to be transformed by 2010, then into what? Presently there is no definitive answer to this, and time is running short. It is probable that there will be some movement into the third e-government developmental phase discussed above, and that ICT-enabled citizen-government interactions will increase. But it is doubtful whether there will be a 'transformation' involving efficiency gains and cost savings, and agency downsizing and mergers. Any transformation may well be in the way officials and the public use ICT in 2010 compared to a decade earlier.

\section{References}

Australian National Audit Office (2005) Measuring the Efficiency and Effectiveness of E-government, Canberra: Australian National Audit Office.

Brown, G. (2004) Statement by the Chancellor of the Exchequer on the 2004 Spending Review, London: HM Treasury, Chancellor of the Exchequer.

Bush, G.W. (2002) 'The importance of e-government', presidential memo, Washington, D.C.: Office of the 
President of the United States, http:// www.whitehouse.gov.omb/egov/g-1-background.html.

Fountain, J. (2001) Building the Virtual State: information technology and institutional change, Washington, D.C.: The Brookings Institution.

Ho, A.T.K. (2002) 'Reinventing local governments and the e-government initiative', Public Administration Review, 64 (2), pp.434-4.

Layne, K. and J. Lee (2001) 'Developing fully functional e-government: a four-stage model', Government Information Quarterly, 18, pp.122-36.

Mahrer, H. and R. Krimmer (2005) 'Towards the enhancement of e-democracy: identifying the notion of the "middleman paradox", Information Systems Journal, 15 (1), pp.27-42.

Mallard, T. (2003) New Zealand E-government Strategy - June 2003 - Update, Wellington: Minister of State Services.

Reddick, C.G. (2005) 'Citizen interaction with egovernment: from the streets to the servers?', Government Information Quarterly, 22 (1), pp.38-57.

Silcock, R. (2001) 'What is e-government?', Parliamentary Affairs, 54, pp.88-101.

State Services Commission (2004) Achieving Egovernment 2004: a report on progress towards the New Zealand e-government strategy, Wellington: State Services Commission.

Robin Gauld is a Senior Lecturer in

Health Policy in the Department of Preventive and Social Medicine,

University of Otago. With Shaun

Goldfinch he is the co-author of

Dangerous Enthusiasms, Amazing Disasters: E-Government, Computer Failures and Public Sector Information Systems Development, Otago University Press, 2006. 